\title{
STUDY MATERIALS FOR FUTURE STUDENTS OF MACHINE DESIGN DEPARTMENT
}

\section{Eduard MüLLER - Martin HYNEK - Miroslav GRACH}

\begin{abstract}
The paper focuses on the training of future students of engineering faculties, especially mechanical design. The project aims to increase the technical expertise of graduates of engineering disciplines for the purpose of better adaptability of graduates in the job market.
\end{abstract}

Key words: Machine Design, study materials, CAD models.

\section{STUDIJNÍ MATERIÁLY PRO BUDOUCÍ STUDENTY TECHNICKÝCH OBORŮ}

Resumé: Př́spěvek se zaměřuje na výuku budoucích studentů strojních fakult, především konstruktérů. Projekt má za úkol zvýšit technickou odbornost absolventů konstrukčních oborů, pro rychlejší adaptaci v praxi.

Klíčová slova: Konstruování strojů, studijní podklady, CAD modely.

\section{1 Úvod}

Počet absolventů technických oborů má v poslední době klesající tendenci a stav na trhu práce již dnes vykazuje nedostatek technicky vzdělaných absolventů prripravených na potřeby průmyslové praxe. Zaměstnavatelé dnes po čerstvých absolventech požadují jazykové znalosti, technickou vyspělost a minimálně praxi s CAD programy. Většina studentů se ve škole zabývá teorií, kterou pak není schopná aplikovat při svém prvním zaměstnání. Zaměstnavatel musí vynakládat nemalé finanční a časové prostředky na školení svých nových pracovníků. To může při dnešním nedostatečném počtu absolventů technických škol značně, časově a finančně zatěžovat malé a střední podniky $\mathrm{v}$ jejich konkurenceschopnosti. $\mathrm{Na}$ tento problém poukazuje studie článku J. Vavrečkové [1], který se zabývá problematikou vzdělaných odborníků a jejich ekonomického vlivu na vývoj států a popisuje přechod vyspělých států $\mathrm{k}$,, ekonomice znalostniho typu. " [1].

Do budoucna je důležité prohlubovat vztahy mezi vysokými školami a průmyslovými podniky. Tuto spolupráci není možné opomíjet, i když je tato činnost $v$ krátkodobém pohledu časově i finančně náročná a nevykazující okamžité benefity oběma stranám. V př́ípadě nečinnosti vzájemné spolupráce, se sníží počet studentů zapojovaných do praktických projektů, při kterých by studenti mohli získávat cenné zkušenosti pro budoucí praxi. $\mathrm{Na}$ tuto problematiku poukazují autoři článku „A makeover for engineering education" [2].
Práce na reálných projektech umožní studentům poznávat procesy vyskytující se v praxi. Díky tomu poroste kvalita vychovaných absolventů a zvýší se jejich uplatnění na trhu práce. Literatura [3] hovoří o „Investice do lidského kapitálu jsou investice do vědy a vzděláni".

$\mathrm{Z}$ toho vyplývá, že je nutné investovat do vzdělávání budoucích studentů vysokých škol. Nejen budováním kvalitního zázemí (laboratoře a učebny), ale především tvorbou nových studijních podkladů, ze kterých studenti budou čerpat znalosti. Studijní materiály jsou dnes vytvářeny akademickými a vědeckými pracovníky na univerzitách $\mathrm{v}$ rámci pracovního poměru a popř́padě studenty, kteři jsou ochotni se zapojit do jejich tvorby. Důležité ale je, aby se na tvorbě podíleli též odborníci z praxe. Ti mohou vyvážit teoretické informace, které se v praxi mnohdy aplikují obtížně a jsou nahrazovány jinými způsoby řešení.

Jedním z řešením jak zvednout kvalitu výuky, je vytvoření databáze realizovaných komplexních projektů z praxe, která by systematicky zvyšovala úroveň praktických znalostí absolventů strojních fakult. Projekty $v$ databázi budou sloužit $\mathrm{k}$ prostudování a následnému řešení obdobných projektů $\mathrm{v}$ rámci semestrálních, bakalářských či diplomových prací. V tomto článku se prezentují nové studijní materiály pro budoucí studenty 
technických oborů se zaměřením na konstrukci, v rámci řešeného projektu „Ukázkové vývojové projekty z praxe pro posílení praktických znalostí budoucích strojních inženýrů (číslo projektu CZ.1.07/2.2.00/28.0056)“ na Fakultě strojní Západočeské univerzity v Plzni (dále jen FST na ZC̈U).

\section{Požadavky na nové studijní materiály}

Před začátkem vytváření takovýchto výukových podkladů, je důležité specifikovat dílčí požadavky kladené na budoucí konstruktéry, aby vhodně obstály $\mathrm{v}$ konkurenčním prostředí. Tyto požadavky sestavila a definovala nezisková organizace ABET (Accreditation Board for Engineering and Technology), $\mathrm{v}$ článku „Criteria for accrediting engineering programs" [4]. $\mathrm{V}$ tomto článku jsou uvedeny schopnosti, kterými by absolventi měli být vybaveni po dokončení studia technického zaměření:

- an ability to apply knowledge of mathematics, science, and engineering

- an ability to design and conduct experiments, as well as to analyze and interpret data

- an ability to design a system, component, or process to meet desired needs within realistic constraints such as economic, environmental, social, political, ethical, health and safety,

manufacturability, and sustainability

- an ability to function on multidisciplinary teams

- an ability to identify, formulate, and solve engineering problems

- an understanding of professional and ethical responsibility

- an ability to communicate effectively

- the broad education necessary to understand the impact of engineering solutions in a global, economic, environmental, and societal context

- a recognition of the need for, and an ability to engage in life-long learning

- a knowledge of contemporary issues

- an ability to use the techniques, skills, and modern engineering tools necessary for engineering practice [4]

Tento obecný výpis nezahrnuje výčet požadavků a praktických dovedností konstruktéra pro jeho budoucí praxi. Proto jsme na základě svých dlouholetých výukových zkušeností sestavily soubor základních vlastností, které má dnešní absolvent konstrukčního oboru mít:

\section{- Schopnost používat CAD software}

- Znalosti navrhování strojírenských procesů

- Znalost výrobních procesů a technologií

- Znalost ekonomických aspektů výroby

- Zkušenosti s reálnými aplikacemi a projekty

- Schopnost vyjadřovat se jednoznačně

- Schopnost komunikovat v cizím jazyce

- Technická tvořivost

- Schopnost analyzovat a formulovat technické problémy

- Znalosti managementu jakosti

Toto jsou podle autorů nejdůležitější schopnosti, které by měl konstruktér ve svém oboru mít. Tyto schopnosti lze těžko získat memorováním definic, obecných postupů či řešením z kontextu vytržených jednoduchých úloh. Proto jsou nové elektronické studijní materiály, soustředěny na reálné konstrukční projekty s komentářem jednotlivých kroků realizace konstrukce od zadání až po výrobní dokumentaci.

\section{Studijní materiály}

Studijní materiály vznikají za podpory strojírenských firem z různých průmyslových odvětví. Tyto firmy poskytly reálné konstrukční projekty, které jsou základem $\mathrm{k}$ vytvárení elektronických studijních podkladů. Studijní materiály jsou zpracovány komplexně a jsou zaměřeny na deset konstrukčních skupin:

- akustické díly

- pohledové díly

- plastové díly

- plechové díly

- licí formy a formy pro zápustkové kování

- frézka

- soustruh

- hydraulický lis

- vulkanizační lis

- manipulační zařízení.

Vytvářené studijní materiály jsou poskytované studentům ve formátu $\mathrm{PDF}$ a $3 \mathrm{D}$ PDF, které obsahují interaktivní CAD modely. Ty jsou hlavním pilírem studijního materiálu a nesou většinu know-how konstruktérské problematiky. Na CAD modelech jsou označeny jednotlivé plochy dle výrobní technologie, popř́ípadě u sestav jsou součásti barveny dle funkce.

Doplňující informace týkající se funkce komponentu, vlastního návrhu nebo výpočtu pro daný stroj či nástroj, jsou zahrnuty ve strukturovaném PDF souboru spolu s výrobní dokumentací. 


\subsection{Popis struktury studijních podkladů}

Pro názornou představu o inovativních studijních podkladech je vybrána ukázka, která zahrnuje popis jedné součásti a funkci jednotlivých komponent, které nástroj obsahuje.
Je zde kladen velký důraz na logické uspořádání jednotlivých kapitol. Každá kapitola obsahuje základní popis nástroje a komponent. Na Obr. 1 je popsána konstrukce prototypového bloku, který je sestaven z bukových překližek.

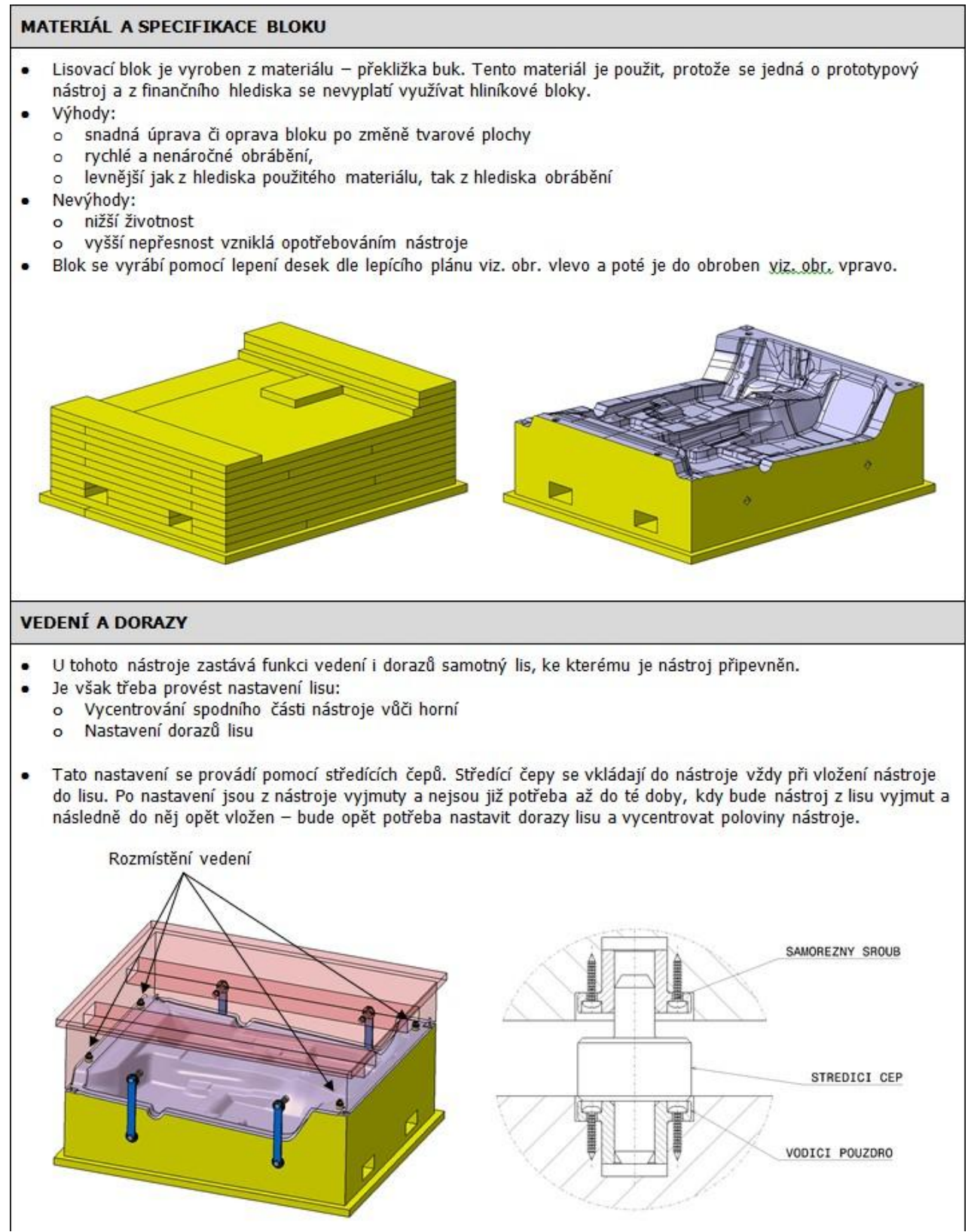

Obr. 1:Popis nástroje

Ty po sestavení vytvoří neopracovaný polotovar, který se vloží do obráběcího stroje. Blok je následně obroben do finálního tvaru. Ukázka dále obsahuje popis funkce vedení a dorazi̊, které jsou rozmístěny v rohách nástroje.

\subsection{Zadávací list}

Další důležitou součástí PDF dokumentů je definování jednotlivých technických specifikací. Ty jsou zahrnuty v tzv. zadávacích listech, které obsahují souhrn požadavků zákazníka na finální výrobek. Definice technických specifikací je prvním krokem při navrhování strojního zařízení. Jednotlivé specifikace musí být přehledně a jednoznačně uspořádány. Zadávací listy obsahují všechny důležité požadavky a podmínky, vztahující se k navrhovanému zařízení.

Je dobrým zvykem tyto zadávací listy psát jako mnohojazyčný dokument. V zadávacím listu 
jsou uvedeny tři jazyky a to český, německý a anglický. Ty byly vybrány na základě jejich významu v plzeňském regionu. Ukázka technických specifikací je znázorněna na obr. 2.
Prrínosem pro studenta je konkrétní představa o tom, co předchází před samostatnou konstrukcí strojního zařízení.

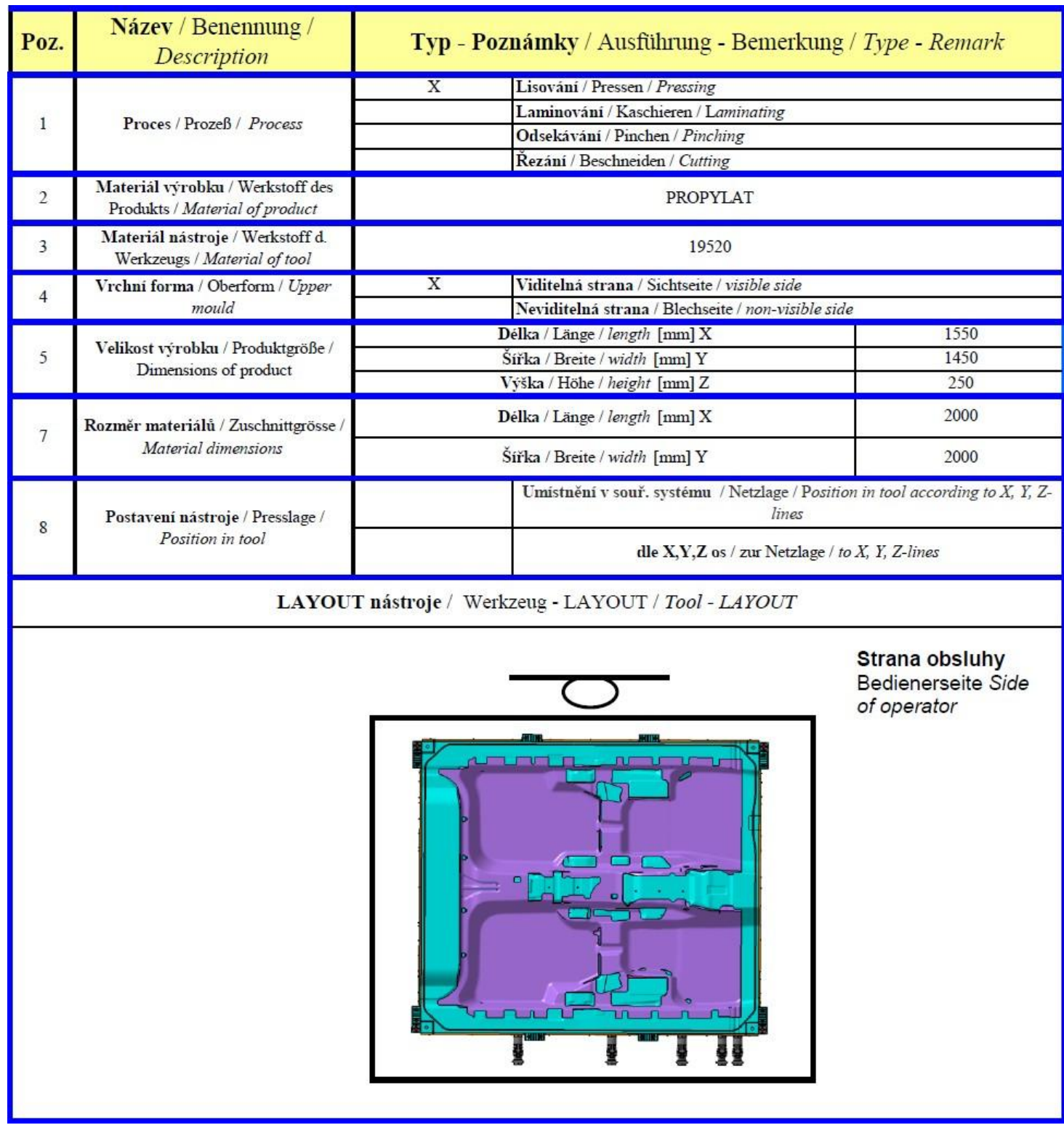

Obr. 2: Zadávací list

Zadávací list je rozdělen do tří sloupců. $\mathrm{V}$ prvním sloupci je zapsána pozice požadavku, dále je uveden název specifikace a $\mathrm{v}$ posledním sloupci (Typ-poznámky) se upřesňují specifikace daného řádku. $V$ príkladu jsou uvedeny rozměry nástroje, druh výroby, materiál dílu a nástroje, postavení obsluhy vůči nástroji.

\subsection{CAD modely}

CAD modely jsou výborným zdrojem znalostí pro studenty v oboru konstruování strojů a jsou jádrem celého projektu. CAD modely jsou vytvářeny $\mathrm{v}$ různých $\mathrm{CAD}$ programech napr.
Catia, Pro-E, Siemens NX, atd. Není možné, aby studenti tyto finančně nákladné softwary vlastnili, $\mathrm{z}$ toho důvodu byla všechna data z jednotlivých CAD programů převedena do souboru 3D PDF.

Nejužitečnější vlastností je možnost prohlížení studijních materiálů na libovolném PC nebo notebooku. Podmínkou je mít nainstalovaný software, který je schopný číst soubory s koncovkou pdf. Toto umožňuje mnoho programů, které jsou volně dostupné s freeware licencí. 
V takto vytvořeném souboru mohou studenti interaktivně prohlížet vybrané uzly studovaného nástroje či stroje. CAD modely je možné otáčet, přibližovat, oddalovat, vytvářet libovolné řezy, jednotlivé komponenty aktivovat a deaktivovat. Při aktivaci se text vybraného modelu zvýrazní a zobrazí se jeho technické specifikace viz obr. 3 . Součásti vyráběné jsou rozepsané $\mathrm{z}$ hlediska označení dílu, čísla dílu a sestavy, hmotnosti, materiálu, atd. Využití prohlížení interaktivních CAD modelů v PDF souboru je oproti výkresové dokumentaci

efektivnější a rychlejší. Především v začátcích studenti mají lepší přehled o daném nástroji či stroji, kdy mají mnohdy problém se zorientovat v běžné výrobní dokumentaci, zvláště u složitějších sestav. Výkresová dokumentace je součástí PDF souboru.
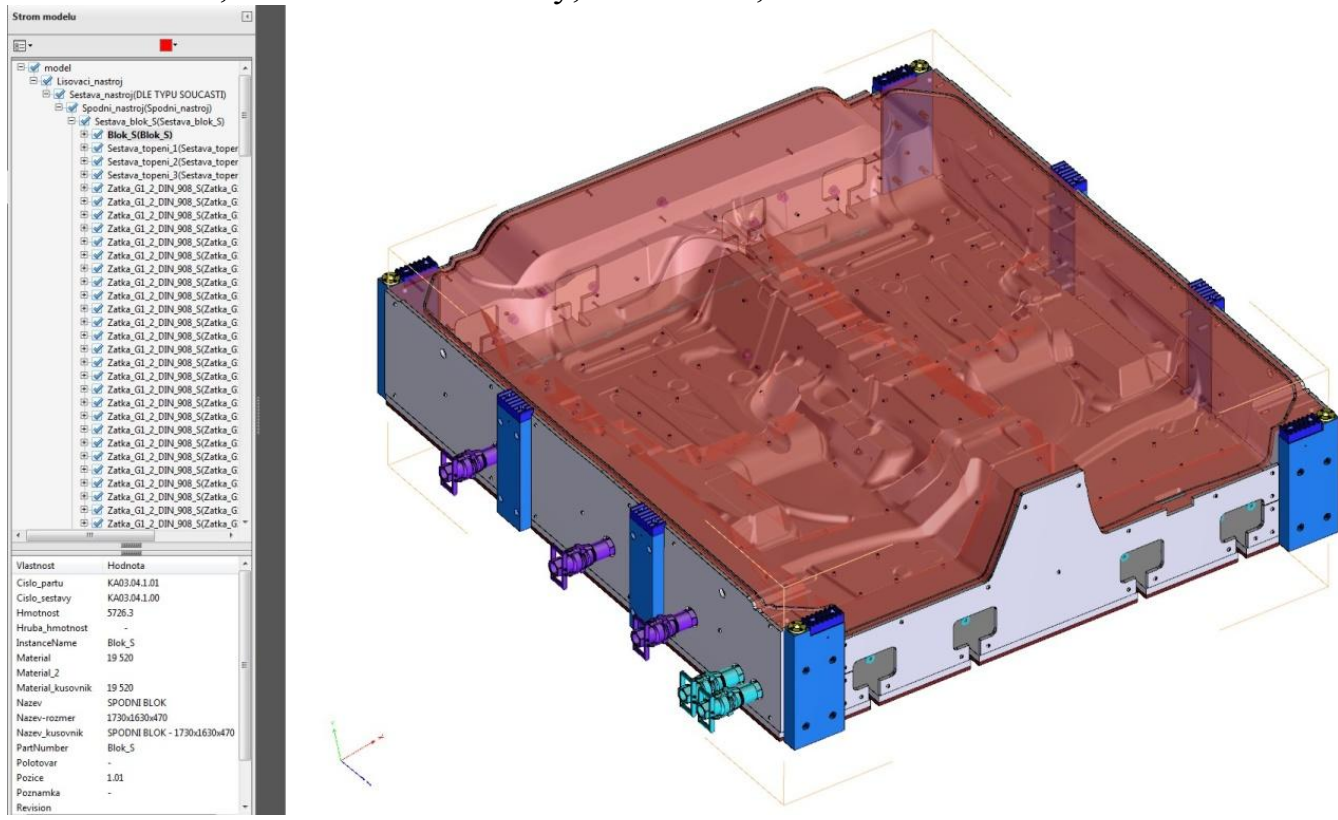

Obr. 3: Aktivni 3D model

Na obr.3 je zobrazen 3D model podsestavy, který je vytvořen z CAD dat. V levém horním okně je zobrazen strom součástí zobrazené sestavy. Pod tímto oknem jsou zobrazeny specifikace vybrané součásti.

CAD modely jsou rozděleny pomocí barev $\mathrm{z}$ hlediska metodiky funkce součásti na nástroji a výrobní technologie. Př́ńnosem je zjednodušená orientace a rychlejší rozpoznání funkce součástí. První definovaná barvená škála označuje stejnou barvu součásti se stejnou funkcí, např. transportní, dorazové, měřící prvky atd. Druhá barevná škála rozlišuje výrobní technologii. Jednotlivé plochy mají přiřazenou barvu, která značí technologii výroby dané geometrie např. vrtání, frézování, řezání atd.

Obr. 4. ukazuje obarvení komponent dle jejich funkcí. V levé části jsou popsány jednotlivé

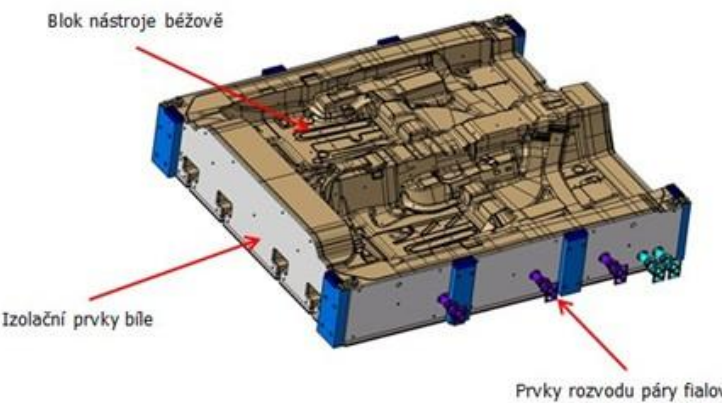

\begin{tabular}{|c|c|c|c|}
\hline \multicolumn{2}{|l|}{ Barva } & RGB & Funkce na modelu \\
\hline HNĚDÁ & $\square=$ & $(128,0,0)$ & aznacóvaci statky \\
\hline FIALOVÁ & $\square$ & $(190,130,255)$ & model dilu \\
\hline ORANŽOVÃ & $=$ & $(255,128,0)$ & prviky pro manipulad a transport nástroje \\
\hline Bíá & - & $(255,255,255)$ & izoløỏni pxvky, tẻsnẻní \\
\hline TMAVẼ Č ČRVENÁ & E. & $(128,0,0)$ & podkladové desky \\
\hline AZUROVÁ & $\square$ & $(0,255,255)$ & prvky pro ochiev \\
\hline TRÁvová & $\square=$ & $(190,230,20)$ & peviky pro chlazeni \\
\hline FIALOVÁ & E. & $(128,0,255)$ & pivky rozvodu páry \\
\hline PURPUROVÁ & 口. & $(255,0,255)$ & prvky rozvodu vakua \\
\hline žLUTÁ & $=$ & $(255,255,0)$ & priky pro vedeni a ustaveni nástroje \\
\hline ČERVENÁ & E. & $(255,0,0)$ & pivky pro ustaveni materialu, dilu, polotovaru \\
\hline BÉżová & $\square=$ & $(211,178,125)$ & Bloky nástroje \\
\hline MODRÁ & . & $(0,128,255)$ & prviky sestavy doraz 0 (mimo vlastnich dorazô) \\
\hline TMAVĚ MODRÁ & E. & $(0,0,255)$ & dorazy nástroje \\
\hline ŠEDÁ & D. & $(126,126,126)$ & stredici proky \\
\hline ZELENÁ & E. & $(0,128,0)$ & méñíi prvky \\
\hline FOSFOROVÁ & D. & $(0,255,0)$ & rámy, upinadi prvky \\
\hline ROŻovÁ & E. & $(255,128,128)$ & krytoráni, plechy nespedajici do finé kategorie \\
\hline
\end{tabular}

Obr. 4: Barevná legenda 
komponenty na nástroji. V pravé části obrázku je zobrazená tabulka legendy popisů komponentů. Tabulka je rozdělena do tří sloupců. První sloupec zobrazuje výpis barev, které jsou na nástroji použity. Prostřední sloupec určuje definici barev podle systému RGB. Třetí sloupec popisuje funkci dané barvy. Uživatel, je tedy schopen rychle a snadno rozpoznat funkci jednotlivých komponent na nástroji.

\section{Př́nos studentům a akademickým pracovníkům}

Hlavním účelem studijních materiálů je inovace výuky FST na ZČU. Materiály poskytují především know-how z různých strojírenských odvětví a napomáhají tak, k celkovému zkvalitnění výuky. Hlavní částí studijních materiálů jsou CAD modely, ty napomáhají studentům rychleji a lépe proniknout do problematiky studované oblasti. Studenti mohou jednotlivé CAD modely prohlížet a studovat z hlediska vazeb, stavby modelů a technologických operací. CAD modely jsou pro větší dostupnost exportovány do formátu $3 \mathrm{D}$ PDF. Pomocí tohoto exportu je možné studijní materiály prohlížet na počítačových stanicích a multimediálních zařízení, které mají nainstalovaný volně dostupný software. Takto vytvořené studijní podklady mohou studenti využít pro školní projekty, semestrální, bakalářské a diplomové práce.

Technické specifikace každého navrhnutého projektu lze snadno modifikovat. Studenti mohou studovat původní návrh projektu a provést jeho úpravy dle změněných technických specifikací a vytvářet tak své vlastní projekty a návrhy. Tímto způsobem získají zkušenosti v daném oboru a jejich konstrukční činnost se přiblíží reálným projektům prováděných ve strojírenské praxi.

Dalším př́nosem je dvojité barvené označení CAD modelů. Součástí každého PDF je legenda jednotlivých barev, které popisují technologické operace a jednotlivé funkce zařízení.

Nové studijní materiály budou zároveň sloužit jako databáze reálných konstrukčních projektů, které budou $\mathrm{k}$ dispozici všem studentům a akademickým pracovníkům FST na ZČU. Tyto konstrukční projekty mohou být použity v rámci jednotlivých předmětů, které se vyučují na ZČU. Vyučované předměty, tak budou obohaceny o cenné know-how a akademičtí pracovníci mohou teoretické základy vysvětlit na projektech z praxe a tudíž lépe přiblížit studentům význam a smysl daných informací.

\section{Závěr}

Během studia je obtížné získávat cenné konstruktérské zkušenosti, které by studenti nabrali při setkání s praktickými projekty. FST na ZČU se zabývá inovací výuky tím, že vytvárí vlastní studijní materiály, které vychází $\mathrm{z}$ reálných projektů řešených $\mathrm{v}$ praxi. Hlavním cílem tohoto článku je prezentovat tuto novou koncepci studijních materiálů. Studijní podklady jsou ve formě strukturovaných PDF, které obsahují popis dané konstrukce spolu s CAD modely a kompletní výrobní dokumentací. Finální CAD modely byly převedeny do formátu 3D PDF, z důvodu prohlížení na libovolném počítači, bez ohledu na nainstalovaný CAD software.

Navazující práce na projektu budou spočívat $\mathrm{v}$ dotazníkovém průzkumu u studentů s cílem identifikování hlavních nedostatků studijních materiáli̊. Projekt je postupně rozšiřován o tyto oblasti: akustické, plastové a plechové díly, frézka, soustruh, licí formy a formy pro zápustkové kování, hydraulický lis, vulkanizační lis a manipulační zařízení. Tyto studijní materiály se začlení do systému kvality výuky na Západočeské univerzitě v Plzni. Jsme přsesvědčeni, že tyto podklady pomohou vychovávat schopnější a kvalitnější konstruktéry, kteří svůj první kontakt s praxí zažijí ještě za doby svého studia a ne až po nástupu do zaměstnání. 


\section{Literatura}

[1] VAVREČKOVÁ, J. (2009) Terciáně vzdělani odborníci a jejich potřeba na českém trhu práce, [Online], Praha. Dostupné z: http://www.vse.cz/polek/download.php?jnl=aop \&pdf $=281$.pdf.

[2] Wm. A. WULF and George M. C. FISHER (2002) A makeover for engineering education, [Online] Dostupné http://www.issues.org/18.3/p_wulf.html

[3] GIBARTI, J. (2006) Budoucnost ČR jako znalostně technologického centra Evropy. In: Znalostna ekonomika - Nove vyzvy pre narodohospodarsku vedu. Zbornik $\mathrm{Z}$ medzinarodnej vedeckej konferencie, Bratislava, 19.-20. oktober 2006. Bratislava : Narodohospodarska fakulta Ekonomickej univerzity, 2006. ISBN 80-225-2249-X.
[4] ABET (2011) Criteria for accrediting engineering programs, [Online], Dostupné $\mathrm{z}$ : http://www.abet.org/uploadedFiles/Accreditation/ Accreditation_Process/Accreditation_Documents /Current/eac-criteria-2012-2013.pdf [22 Jan 2012].

doc. Ing. Martin Hynek, Ph.D.,

Ing. Eduard Müller

Ing. Miroslav Grach

Katedra konstruování strojů

Fakulta strojní FST

Univerzitní ul. č. 22

30614 Plzeň, ČR

Tel: +420 377638 296,

E-mail: emuller@kks.zcu.cz

Www pracoviště: www.kks.zcu.cz

Tento článek je spolufinancován Evropským sociálním fondem a státním rozpočtem České republiky v rámci projektu č. CZ.1.07/2.2.00/28.0056 „Ukázkové vývojové projekty z praxe pro posílení praktických znalostí budoucích strojních inženýrư“.
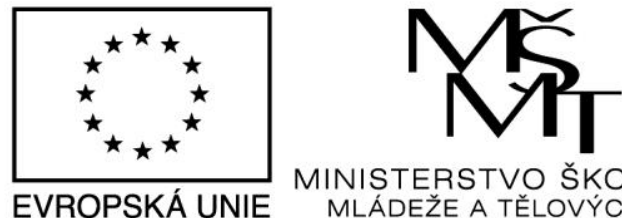

MINISTERSTVO ŠKOLSTVÍ, MLÁDEŽE A TĚLOVÝCHOVY

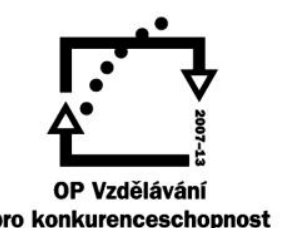

pro konkurenceschopnost

INVESTICE DO ROZVOJE VZDĚLÁVÁNÍ 